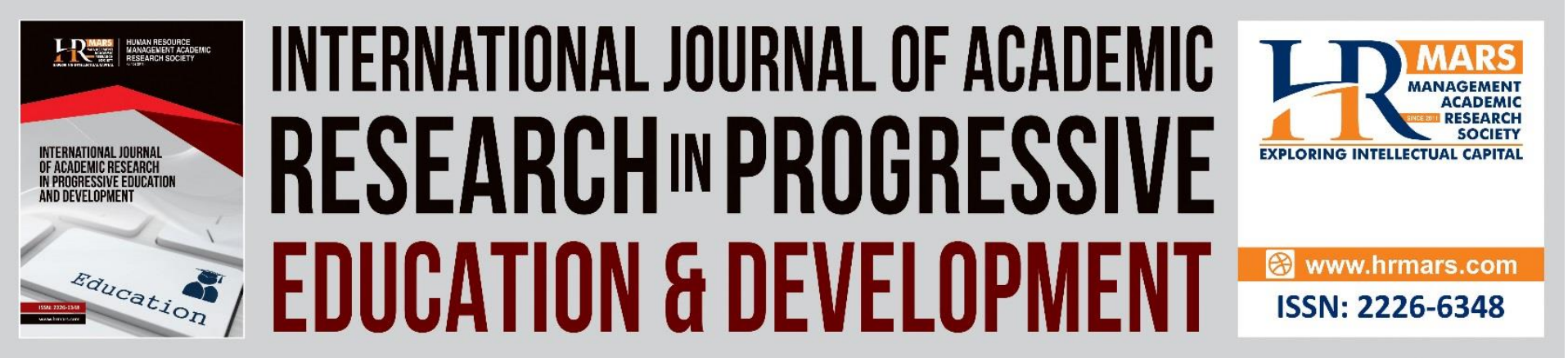

\title{
Agricultural Video as A Learning Medium for Young Farmer
}

\author{
Mohd Hafifi Paudi, Rosseni Din, Nabilah Othman
}

To Link this Article: http://dx.doi.org/10.6007/IJARPED/v11-i1/12142

DOI:10.6007/IJARPED/v11-i1/12142

Received: 02 November 2021, Revised: 28 November 2021, Accepted: 17 December 2021

Published Online: 19 January 2022

In-Text Citation: (Paudi et al., 2022)

To Cite this Article: Paudi, M. H., Din, R., \& Othman, N. (2022). Agricultural Video as A Learning Medium for Young Farmer. International Journal of Academic Research in Progressive Education and Development, 11(1), 729-742.

Copyright: (C) 2022 The Author(s)

Published by Human Resource Management Academic Research Society (www.hrmars.com)

This article is published under the Creative Commons Attribution (CC BY 4.0) license. Anyone may reproduce, distribute, translate and create derivative works of this article (for both commercial and non-commercial purposes), subject to full attribution to the original publication and authors. The full terms of this license may be seen

at: http://creativecommons.org/licences/by/4.0/legalcode

\section{Vol. 11(1) 2022, Pg. 729 - 742}

Full Terms \& Conditions of access and use can be found at http://hrmars.com/index.php/pages/detail/publication-ethics 


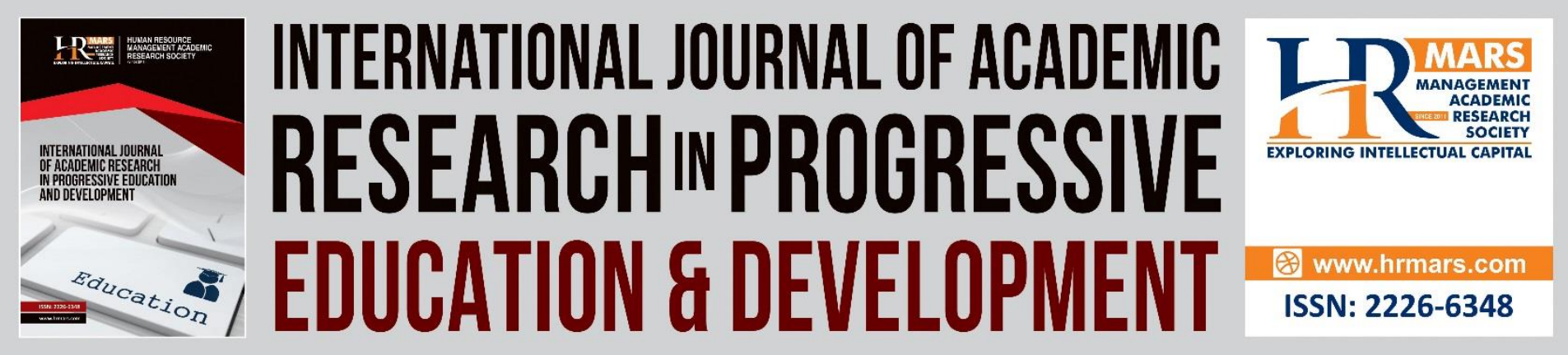

\title{
Agricultural Video as A Learning Medium for Young Farmer
}

\author{
Mohd Hafifi Paudi \\ Faculty of Education, Universiti Kebangsaan Malaysia, 43600 UKM Bangi, Selangor, Malaysia \\ Email: p106010@siswa.ukm.edu.my \\ Rosseni Din \\ STEM Enculturation Research Centre, Faculty of Education, Universiti Kebangsaan Malaysia, \\ 43600 UKM Bangi, Selangor, Malaysia \\ Email: rosseni@ukm.edu.my

\begin{abstract}
Nabilah Othman
Information Technology \& Resources Module, Faculty of Education, Universiti Kebangsaan Malaysia, 43600 UKM Bangi, Selangor,Malaysia

Email: cik.nabilah001@gmail.com
\end{abstract}

\begin{abstract}
The aim of this study is to identify if learning using video for sharing agricultural activities through YouTube can increase young farmers' interest and skills. Now the concept of video in social media provides a self-learning environment with the help of information and communication technology tools. This tool is a simulation that allows farmers to experience a real learning experience and be able to interact with other farmers without having face-toface encounters. This facility becomes the best expansion agent that demands farmers to constantly update their knowledge and skills throughout their lives. The studies carried out the survey method using a questionnaire to collect research data. A total of 66 young farmers consisting of farmers in the districts of Jeli, Kuala Krai, and Gua Musang in the Kelantan, Malaysia was selected as respondents. Data for this study analyzed descriptively by using SPSS ver22 software. The findings show the use of learning materials such as videos give the positive impact that can improve the skills and knowledge of farmers in agricultural activities. The finding also showed that video can reduce cognitive load as well as save time, energy and cost to obtain something new information in the field of agriculture. The findings of this study are expected to help individuals who want to venture into the field of agriculture to increase the level of knowledge, understanding, and readiness for self-learning farming methods. It is clear that this video-based learning technology opens up many new opportunities to be explored by change agents in enhancing the learning potential of youth. Therefore, proposed that further research is related to the potential and impact of the latest technologies that can add value from the perspective of Risale-i Nur to existing video technologies.
\end{abstract}


DEVELOPMENT

Vol. 11, No. 1, 2022, E-ISSN: 2226-6348 @ 2022 HRMARS

Keywords: Agricultural Videos, Self -Learning, Digital Devices.

\section{Introduction}

The development of Information and Communication Technology (ICT) today has had a huge impact on human life. It provides many benefits in our life activities in accordance with the role of technology to help improve the quality of human life. ICT also assists in the development of Teaching and Learning materials (T\&L) through various forms to increase diversity in resources and teaching aids in order to ensure that the T\&L process can be carried out continuously and effectively. At the same time, the majority of human beings today do indeed have digital devices such as smartphones and wireless networks that allow them to use a variety of resources and learning materials or channels regardless of time on their own. Therefore, those who have digital devices and access information from the right materials and sources will drive a self-learning process in improving their quality of life.

Based on a study conducted by Akmal et al (2021), the use of video through social media can increase the effectiveness of learning activities through the mechanism of involvement. Multimedia technology can attract interest and further improve their performance and make the learning experience more effective. This method is suitable to be integrated in the lives of farmers where the ability of video documentation or sharing can be practiced in the real world through digital devices such as phones and tablets when the information can be provided to farmers at the right time and place.

The agricultural sector is a contributor to the foundation of economic formation for Malaysia in the post-independence era with a contribution to Gross Domestic Product (GDP) of 46.0 percent in 1957. This sector continues to grow with a contribution of RM 99.5 billion in 2018. The Covid-19 Pandemic crisis continues to worsen and threaten the world economy as well as employment opportunities which becomes a major issue for the country. One opportunity that the government needs to open up for unemployed youths out there is by filling and planning the agricultural sector. According to Labor Force Statistics by the Department of Statistics Malaysia (DOSM), there is a total of 742700 people or 4.6 percent unemployment rate until April 2021 in Malaysia.

The youths are valuable asset to the country because they are the heirs who will continue the country's development and are the most important source of manpower. Human resources, which are the pillars of this country, must be developed and mobilized to become partners in the development of quality and productive resources. The Malaysian government through its development program has never forgotten to formulate an agenda on youth education towards agriculture in every policy and action plans. Opportunities to venture into agriculture are always open to them and support from various aspects is always given to ensure the success of these youths' careers in the agricultural sector.

The term youth farmer is a concept that encourages youths to venture into agriculture. Youths who are capable of fulfilling the hopes of the future nation are excellent peasant youths who continue to make strides to become a nucleus farmer. They are also responsible for leading the management of agriculture and contributing to the agricultural activity for their area of residence. Youth farmers like this are expected to be the backbone of agriculture to replace the generation of farmers who are getting older with age. They must follow the changes and 
progress of today's world which raises various issues and matters that affect the development of agriculture-youth in Malaysia.

By 2050 the world population is expected to increase by 9.8 billion and the world's food demand at that time is expected to increase by up to 70 percent. Existing farming methods not able to meet this increasing food requirement. Domestically, we still need to import 30 percent of the rice supply to meet local needs. In the event of an unwanted natural disaster such as a million-locust attack in India, it can affect the country's import supply. A frequently debated technology to overcome this problem is the Precise Farming method that emerged from the Internet of Things (IoT) phenomenon. This technology is categorized as "disruptive technology" because it will change normal process norms to new norms.

Developments towards the use of technology in the agricultural sector have made teaching and learning activities more sophisticated, futuristic and in line with the changes of the latest information technology era (Vizcaya-Moreno \& Perez-Canaveras, 2020). The use of technology has also provided various opportunities for farmers to practice information sharing and increase knowledge delivered through electronic technology facilities such as email, website, forum, smartphones, blogs and social media which are more interesting (Kom, 2020). In addition, the e-learning approach that led to online discussions has also created collaborative networks in the community for learning purposes as well as information skills and self-access learning for educational needs of the 21st century.

Appropriate sharing techniques based on the latest technology should be mastered by change agents so that the T\&L process at the youth level can be used widely to encourage youth interest in mastering knowledge and exposure to interactive and interesting learning processes in life (Hanifah, 2020). On the other hand, conventional learning in the form of chalk and talk and relying entirely on teachers and white boards is less suitable to be practiced in the current net generation (Baharudin \& Ibrahim, 2020). Youths need to be exposed to the use of ICT such as social media that can provide skills for informative information and knowledge in the teaching and learning process in the classroom (Narzullayevna, 2020). The use of video streaming media, such as YouTube is very popular and influential. It has been widely used in the medium of T\&L and it is important in the development of the modern world of education today (Zulazizi, 2020).

The YouTube app is a user-uploaded video sharing site that allows users to watch and share video clips. The findings of a study by Sudarsana et al (2019) found that online videos such as YouTube have been used a lot in learning in the classroom and thus widely used in courses in addition to podcasts, wikis and blogs. YouTube is also used by young farmers for the purpose of collaborative learning and to encourage self-learning and help online learning as well as to be an educational instrument to enhance learning in an innovative and creative way (Albahiri \& Alhaj, 2020).

There are many past research findings that are positively contributing through the use of YouTube videos that have contributed to individual involvement in the classroom more actively and not passively (Bayuong et al., 2019). According to Wael (2016), advantages of YouTube video in self-learning activities are fast feedback and reinforcement as well as multimedia integration from various sources (Hanifah, 2020). Farmers do not have time to 
follow the learning directly due to the busyness in the field. Watching videos on social media applications can flexibly help increase the knowledge of the youth more effectively without involving the time and cost that must be sacrificed in order to obtain new knowledge related to agricultural technology.

Finally, quality and effective sharing results cannot be fully achieved through conventional methods because this agricultural knowledge has limited time with extensive lesson content (Kurniawan, 2020). Thus, the way to delivery or sharing style of agricultural development agents should be changed using different methods. For example, by using media technology approach through the use of YouTube videos despite the fact that it is difficult to change something that has long been a habit (Annisa, 2020). Through the problems mentioned, then the relevant teaching approach can be applied in the agriculture T\&L session of agriculture so that young farmers can master the skills and understanding better.

Therefore, this study aims to identify if learning using video for sharing agricultural activities through YouTube can increase youth interest and skills. Furthermore, the study aims to identify the mean and standard deviation of acceptance factors and the contribution of video use on youth knowledge and access to adult learning. The research questions (RQ) are as follows:

i. To what extent does agricultural knowledge contribute to improved access to education and training?

ii. What is the youth perception of the use of agricultural videos?

iii. What is the contribution of agricultural education videos on youth skills?

\section{Methodology}

This study involves agricultural youths who carry out traditional agricultural activities. According to the Sample Size Table by (Krejcie \& Morgan, 1970) for a population size of 80 peasant youths, the required sample size is 66 peasant youths. A total of 66 farmer youths ( 55 males and 11 females) from Jeli, Kuala Krai and Gua Musang districts were involved in this study. The study uses a questionnaire as a research instrument to obtain data from study respondents. A set of questionnaires was used which was adapted from (Shahila \& Khalid, 2021) to determine the perceptions of peasant youth on the knowledge of the use of video in the teaching and learning process. The instrument consists of two parts, namely part $A$ is demographic information and part $B$ is an item to measure perceptions of knowledge. This questionnaire uses a Likert Scale [1] = Strongly Disagree [2] = Disagree [3] = Not Sure [4] = Agree [5] = Strongly Agree. This study was conducted to obtain feedback related to agricultural knowledge among agricultural youths. The duration of the implementation is 2 weeks to complete the task given to build a web platform to manage existing agricultural videos according to the theme. Farmer youths are required to access the web platform to watch the video. The web displays three forms of agricultural video content such as Agricultural Technology, Smart Agriculture and Partnership. Subsequently the respondents were ask to make reflection on the video they watched.

There are three sections of agriculture related videos that have been taken through social media applications such as Facebook, YouTube and other resources for this project. The design development of the resources were based on Universal Design Model for Agile 
Development (UDin Model) (Din, 2016, 2020) as in Figure 1. This model is a combination of several instructional design models and software engineering models. This model is suitable for the development of teaching materials that is combined into one teaching system. Briefly, this model is for the production of a new product or system. First one need to clarify Learning Outcomes before defining other processes. To ensure the product will achieve the learning outcome through 'Evaluation' process, the assessment procedure and activities need to be determined. Instructional design in this model focuses on five elements namely Content, Values, Theory, Pedagogy and Strategies. As for product effectiveness testing, it needs to go through four phases as follows: Phase 1: Usability, analysis, and specification of user needs, Phase 2: Design, development and usability testing 1, Phase 3: Implementation, usability testing 2 and maintenance, Phase 4: Study impact, modeling and ROI. This study will only test usability and acceptance of the resources via respondence perceptions.

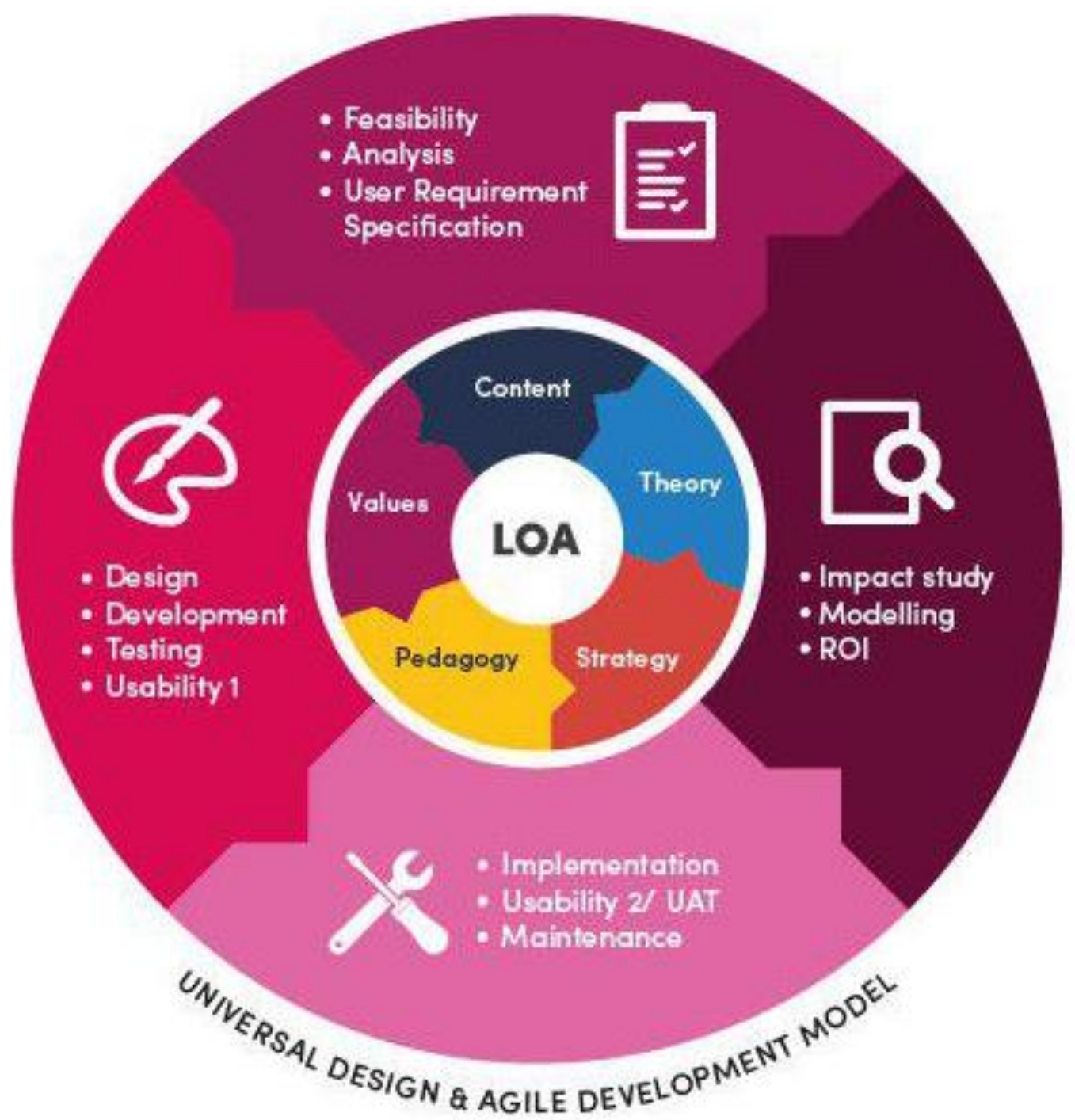

Figure 1: Universal Design Model for Lewes Development (UDin Model).

Agricultural videos available on social media applications were selected for this project based on four elements in the Multiple Intelligences theory. This is because, each individual has their own learning style. The video was selected based on the Linguistic, Visual Spatial, Naturalistic and Musical components. After the agricultural video is selected, the video is uploaded to 
INTERNATIONAL JOURNAL OF ACADEMIC RESEARCH IN PROGRESSIVE EDUCATION AND

DEVELOPMENT

Vol. 11, No. 1, 2022, E-ISSN: 2226-6348 @ 2022 HRMARS

the web platform Weebly at http://e-agroteknologi.weebly.com. Figure 2 shows the important items in the development of this e-learning system. There are three modules in the video section namely Agricultural Technology, Smart Agriculture and Partnership.

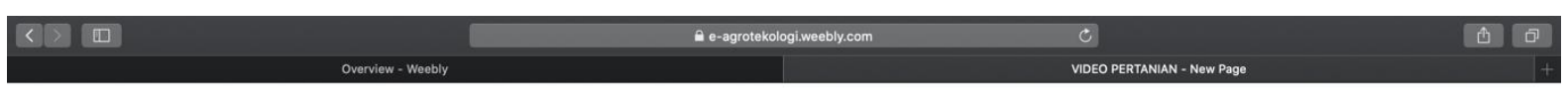

VIDEO PERTANIAN

New PAGE VIDEO REFLEKSI LAIN-LAIN LINK PAGE

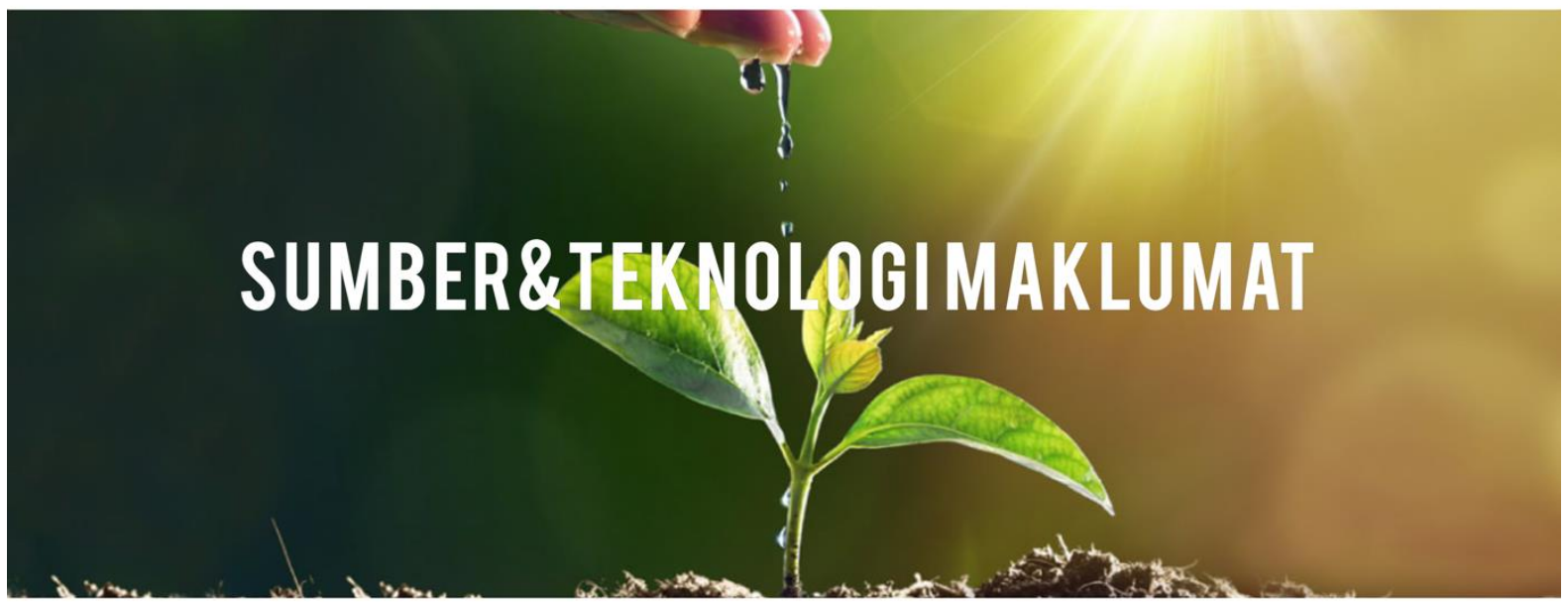

POWERED BY Weebly

Pertanian merupakan sektor penting dalam pembangunan sosio-ekonomi negara. Bidang pertanian

Figure 2: Weebly web platform interface screen

Figure 3 shows the video display available on the web platform for video suitability by category. 


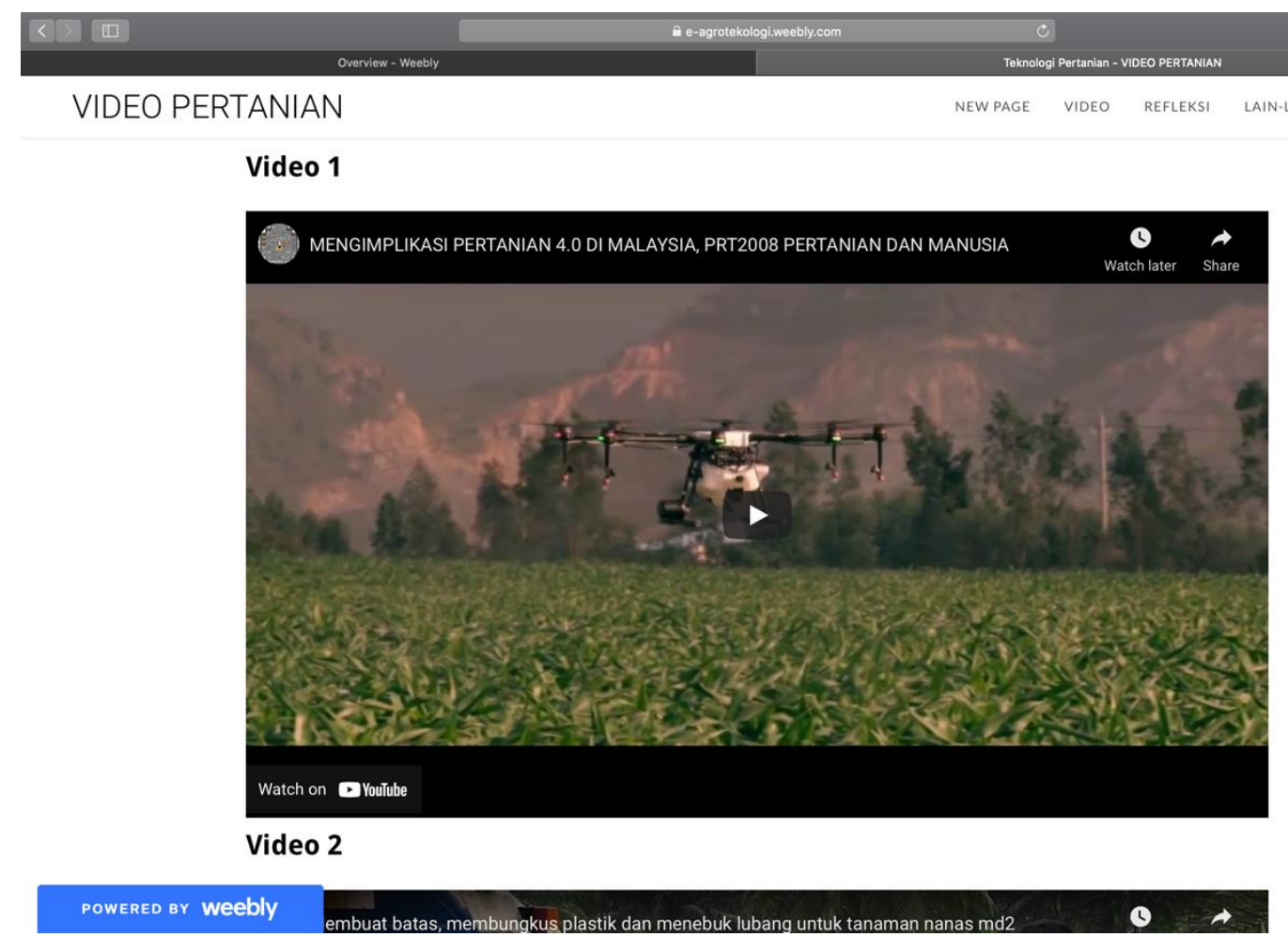

Figure 3: Video screens by category.

Data before and after the experiment were analyzed quantitatively for each respondent involved. These data will be compared before and after the use of video to see the reflection of the results of using the resources. Study data obtained from the questionnaires were collected from respondents and processed with IBM SPSS Statistics version 26. Data were analyzed according to the study questions. The demographic segments analyzed will be reported using percentages and frequencies. While the value of analysis in the form of mean and standard deviation is used to answer the questions of this study.

\section{Results \& Discussion}

A total of 66 respondents were randomly selected from the total population of 80 peasant youths, $83.3 \%$ were male respondents while $16.7 \%$ were female respondents. The majority of $78.8 \%$ of peasant youths are in the age range of 25 to 30 years, $15.2 \%$ of peasant youths are in the age range of 20 to 24 years, the remaining $6.1 \%$ of peasant youths are in the age range of 15 to 19 years. While the level of education of the respondents is $72.7 \%$ of the peasant youths have SPM or High School Certification, $15.2 \%$ of the peasant youths have a STPM or Diploma, as many as $12.1 \%$ of the peasant youths have a degree. As for the agricultural activities carried out by the respondents, $89.4 \%$ carry out subsistence farming activities while as many as $10.6 \%$ carry out agricultural activities on farms. Next, the use of operating system for digital devices used by each respondent is $71.2 \%$ are Android system, $16.7 \%$ iOS system, $6.1 \%$ Windows system and $6.1 \%$ are other systems. There are $100.0 \%$ of peasant youths accessing videos in their daily lives. 


\section{Use of Video to Increase Knowledge about Agriculture}

Based on the findings in Table 1, the overall mean for the use of video as a learning resource for agriculture is 4.14, which is at a high level. In detail the findings show that all items are at a high level. The percentage distribution for item 3, shows that more respondents agree $(78.8 \%)$ that they can access various videos needed to increase knowledge in a particular method or technique of farming required through video especially in social applications. Other items also showed that most respondents agreed on access to training and education using videos about agriculture can encourage themselves and their interest in agricultural activities.

Table 1: Findings of access to training and education.

\begin{tabular}{|c|c|c|c|c|c|c|}
\hline \multirow[t]{2}{*}{ No. } & \multirow[t]{2}{*}{ Items } & \multicolumn{5}{|c|}{$\begin{array}{l}\text { Frequency }(\mathrm{N}) \\
\text { (Percent \%) }\end{array}$} \\
\hline & & STS & TS & TP & $\mathrm{S}$ & SS \\
\hline 1. & $\begin{array}{l}\text { I can use search engines to browse } \\
\text { information. }\end{array}$ & $\begin{array}{l}0 \\
(0.0 \%)\end{array}$ & $\begin{array}{l}0 \\
(0.0 \%)\end{array}$ & $\begin{array}{l}4 \\
(6.1 \%)\end{array}$ & $\begin{array}{l}44 \\
(66.7 \%)\end{array}$ & $\begin{array}{l}18 \\
(27.3 \%)\end{array}$ \\
\hline 2. & $\begin{array}{l}\text { I know how to use social media apps } \\
\text { to share information with other } \\
\text { young farmers. }\end{array}$ & $\begin{array}{l}0 \\
(0.0 \%)\end{array}$ & $\begin{array}{l}0 \\
(0.0 \%)\end{array}$ & $\begin{array}{l}3 \\
(4.5 \%)\end{array}$ & $\begin{array}{l}48 \\
(72.7 \%)\end{array}$ & $\begin{array}{l}15 \\
(22.7 \%)\end{array}$ \\
\hline 3. & $\begin{array}{l}\text { I can use a variety of strategies to } \\
\text { encourage the learning process by } \\
\text { using video. }\end{array}$ & $\begin{array}{l}0 \\
(0.0 \%)\end{array}$ & $\begin{array}{l}0 \\
(0.0 \%)\end{array}$ & $\begin{array}{l}3 \\
(4.5 \%)\end{array}$ & $\begin{array}{l}52 \\
(78.8 \%)\end{array}$ & $\begin{array}{l}11 \\
(16.7 \%)\end{array}$ \\
\hline 4. & $\begin{array}{l}\text { I may use downloads/uploads } \\
\text { feature for sharing purpose. }\end{array}$ & $\begin{array}{l}0 \\
(0.0 \%)\end{array}$ & $\begin{array}{l}0 \\
(0.0 \%)\end{array}$ & $\begin{array}{l}5 \\
(7.6 \%)\end{array}$ & $\begin{array}{l}48 \\
(72.7 \%)\end{array}$ & $\begin{array}{l}13 \\
(19.7 \%)\end{array}$ \\
\hline 5. & $\begin{array}{l}\text { I know how to evaluate when/how } \\
\text { videos can diversify my farming } \\
\text { activities. }\end{array}$ & $\begin{array}{l}0 \\
(0.0 \%)\end{array}$ & $\begin{array}{l}0 \\
(0.0 \%)\end{array}$ & $\begin{array}{l}9 \\
(13.6 \%)\end{array}$ & $\begin{array}{l}45 \\
(68.2 \%)\end{array}$ & $\begin{array}{l}12 \\
(18.2 \%)\end{array}$ \\
\hline 6. & $\begin{array}{l}\text { I was able to find new technology } \\
\text { learning opportunities to improve } \\
\text { my knowledge and skills. }\end{array}$ & $\begin{array}{l}0 \\
(0.0 \%)\end{array}$ & $\begin{array}{l}0 \\
(0.0 \%)\end{array}$ & $\begin{array}{l}3 \\
(4.5 \%)\end{array}$ & $\begin{array}{l}48 \\
(72.7 \%)\end{array}$ & $\begin{array}{l}15 \\
(22.7 \%)\end{array}$ \\
\hline 7. & $\begin{array}{l}\text { I can design/build learning activities } \\
\text { through video that I can integrate } \\
\text { into everyday life. }\end{array}$ & $\begin{array}{l}0 \\
(0.0 \%)\end{array}$ & $\begin{array}{l}0 \\
(0.0 \%)\end{array}$ & $\begin{array}{l}3 \\
(4.5 \%)\end{array}$ & $\begin{array}{l}49 \\
(74.2 \%)\end{array}$ & $\begin{array}{l}14 \\
(21.2 \%)\end{array}$ \\
\hline 8. & $\begin{array}{l}\text { I am able to make my own video } \\
\text { sharing for the convenience of } \\
\text { other young farmers making } \\
\text { reference. }\end{array}$ & $\begin{array}{l}0 \\
(0.0 \%)\end{array}$ & $\begin{array}{l}0 \\
(0.0 \%)\end{array}$ & $\begin{array}{l}4 \\
(6.1 \%)\end{array}$ & $\begin{array}{l}52 \\
(78.8 \%)\end{array}$ & $\begin{array}{l}10 \\
(15.2 \%)\end{array}$ \\
\hline \multicolumn{2}{|c|}{ Total Mean } & \multicolumn{5}{|l|}{4.14} \\
\hline
\end{tabular}

The findings of this study are in line with the study of Ishak \& Khalid (2021) who found that multimedia technology tools can provide a positive effect in the process of information delivery because it can attract attention and help provide an accurate picture along with the information presented in all fields of knowledge. 


\section{DEVELOPMENT}

Vol. 11, No. 1, 2022, E-ISSN: 2226-6348 @ 2022 HRMARS

\section{Use of Agriculture Video in Self -learning for Agricultural Youth}

Based on the findings in Table 2, the overall mean for the acceptance of Agriculture video for self -learning is 4.17 which is at a high level. In detail the findings show that all items are at a high level. The percentage distribution for items 1 and 5, showed that more respondents agreed (78.8\%) that video can reduce cognitive load as well as save time, energy and cost to obtain something new information in the field of agriculture. This finding is in line with the study of Ibrahim et al (2021) that the use of multimedia technology can have a positive impact on the development of learning.

Table 2: The effect of video on agricultural youth learning

\begin{tabular}{|c|c|c|c|c|c|c|}
\hline \multirow[t]{2}{*}{ No. } & \multirow[t]{2}{*}{ Items } & \multicolumn{5}{|c|}{$\begin{array}{l}\text { Frequency }(\mathrm{N}) \\
\text { (Percent \%) }\end{array}$} \\
\hline & & STS & TS & TP & $\mathrm{S}$ & SS \\
\hline 1. & Video can reduce cognitive load. & $\begin{array}{l}0 \\
(0.0 \%)\end{array}$ & $\begin{array}{l}0 \\
(0.0 \%)\end{array}$ & $\begin{array}{l}1 \\
(1.5 \%)\end{array}$ & $\begin{array}{l}52 \\
(78.8 \%)\end{array}$ & $\begin{array}{l}13 \\
(19.7 \%)\end{array}$ \\
\hline 2. & $\begin{array}{l}\text { Videos can provide a clear and } \\
\text { accurate understanding of the } \\
\text { content. }\end{array}$ & $\begin{array}{l}0 \\
(0.0 \%)\end{array}$ & $\begin{array}{l}0 \\
(0.0 \%)\end{array}$ & $\begin{array}{l}4 \\
(6.1 \%)\end{array}$ & $\begin{array}{l}45 \\
(68.2 \%)\end{array}$ & $\begin{array}{l}17 \\
(25.8 \%)\end{array}$ \\
\hline 3. & $\begin{array}{l}\text { Videos can help me understand } \\
\text { difficult concepts. }\end{array}$ & $\begin{array}{l}0 \\
(0.0 \%)\end{array}$ & $\begin{array}{l}0 \\
(0.0 \%)\end{array}$ & $\begin{array}{l}2 \\
(3.0 \%)\end{array}$ & $\begin{array}{l}50 \\
(75.8 \%)\end{array}$ & $\begin{array}{l}14 \\
(21.2 \%)\end{array}$ \\
\hline 4. & $\begin{array}{l}\text { Videos are able to present } \\
\text { information in a more realistic way } \\
\text { that resembles a real situation. }\end{array}$ & $\begin{array}{l}0 \\
(0.0 \%)\end{array}$ & $\begin{array}{l}0 \\
(0.0 \%)\end{array}$ & $\begin{array}{l}4 \\
(6.1 \%)\end{array}$ & $\begin{array}{l}50 \\
(75.8 \%)\end{array}$ & $\begin{array}{l}12 \\
(18.2 \%)\end{array}$ \\
\hline 5. & $\begin{array}{l}\text { Using video can save time, energy, } \\
\text { and cost. }\end{array}$ & $\begin{array}{l}0 \\
(0.0 \%)\end{array}$ & $\begin{array}{l}0 \\
(0.0 \%)\end{array}$ & $\begin{array}{l}1 \\
(1.5 \%)\end{array}$ & $\begin{array}{l}52 \\
(78.8 \%)\end{array}$ & $\begin{array}{l}13 \\
(19.7 \%)\end{array}$ \\
\hline \multicolumn{2}{|c|}{ Total Mean } & \multicolumn{5}{|l|}{4.17} \\
\hline
\end{tabular}

\section{Acceptance of young farmers towards Agriculture videos?}

Table 4 displays the results of the total mean for the item of agricultural youth acceptance towards agricultural video which is 4.25 at a high level. In short, it shows a high distribution value on the agree score, on items 1 and 6 respectively with the same value that is $(72.7 \%)$. This means the video containing agricultural knowledge is able to inspire the farming youths to use the method as guidance for farming in their agricultural activities. 
Table 4: Acceptance of Agriculture videos among farmer youth

\begin{tabular}{|c|c|c|c|c|c|c|}
\hline \multirow[t]{2}{*}{ No. } & \multirow[t]{2}{*}{ Items } & \multicolumn{5}{|c|}{$\begin{array}{l}\text { Frequency }(\mathrm{N}) \\
(\text { Percent \%) }\end{array}$} \\
\hline & & STS & TS & TP & $\mathrm{S}$ & SS \\
\hline 1. & $\begin{array}{l}\text { Agricultural videos can provide } \\
\text { thoughtful ideas in planning to use } \\
\text { new innovations/technologies. }\end{array}$ & $\begin{array}{l}0 \\
(0.0 \%)\end{array}$ & $\begin{array}{l}0 \\
(0.0 \%)\end{array}$ & $\begin{array}{l}1 \\
(1.5 \%)\end{array}$ & $\begin{array}{l}48 \\
(72.7 \%)\end{array}$ & $\begin{array}{l}17 \\
(25.8 \%)\end{array}$ \\
\hline 2. & $\begin{array}{l}\text { Agricultural videos can influence } \\
\text { farmers to accept new produc/ } \\
\text { technology innovations. }\end{array}$ & $\begin{array}{l}0 \\
(0.0 \%)\end{array}$ & $\begin{array}{l}0 \\
(0.0 \%)\end{array}$ & $\begin{array}{l}1 \\
(1.5 \%)\end{array}$ & $\begin{array}{l}42 \\
(63.6 \%)\end{array}$ & $\begin{array}{l}23 \\
(34.8 \%)\end{array}$ \\
\hline 3. & $\begin{array}{l}\text { Agricultural videos can also give } \\
\text { understanding } \\
\text { needs/expectations of young } \\
\text { farmers on the use of new } \\
\text { innovations/technologies. }\end{array}$ & $\begin{array}{l}0 \\
(0.0 \%)\end{array}$ & $\begin{array}{l}0 \\
(0.0 \%)\end{array}$ & $\begin{array}{l}3 \\
(4.5 \%)\end{array}$ & $\begin{array}{l}44 \\
(66.7 \%)\end{array}$ & $\begin{array}{l}19 \\
(28.8 \%)\end{array}$ \\
\hline 4. & $\begin{array}{l}\text { Video is also able to improve youth } \\
\text { skills in the use of new product } \\
\text { innovations. }\end{array}$ & $\begin{array}{l}0 \\
(0.0 \%)\end{array}$ & $\begin{array}{l}0 \\
(0.0 \%)\end{array}$ & $\begin{array}{l}0 \\
(0.0 \%)\end{array}$ & $\begin{array}{l}46 \\
(69.7 \%)\end{array}$ & $\begin{array}{l}20 \\
(30.3 \%)\end{array}$ \\
\hline 5. & $\begin{array}{l}\text { Agricultural videos can convince } \\
\text { farmers with new product } \\
\text { innovations presented. }\end{array}$ & $\begin{array}{l}0 \\
(0.0 \%)\end{array}$ & $\begin{array}{l}0 \\
(0.0 \%)\end{array}$ & $\begin{array}{l}3 \\
(4.5 \%)\end{array}$ & $\begin{array}{l}46 \\
(69.7 \%)\end{array}$ & $\begin{array}{l}17 \\
(25.8 \%)\end{array}$ \\
\hline & $\begin{array}{l}\text { Agricultural videos can evaluate } \\
\text { new product innovations that are } \\
\text { relevant to youth skills. }\end{array}$ & $\begin{array}{l}0 \\
(0.0 \%)\end{array}$ & $\begin{array}{l}0 \\
(0.0 \%)\end{array}$ & $\begin{array}{l}3 \\
(4.5 \%)\end{array}$ & $\begin{array}{l}48 \\
(72.7 \%)\end{array}$ & $\begin{array}{l}15 \\
(22.7 \%)\end{array}$ \\
\hline \multicolumn{2}{|c|}{ Total Mean } & \multicolumn{5}{|l|}{4.25} \\
\hline
\end{tabular}

The use of video in this study suggests alternatives in the implementation of agricultural training and education that can save costs and impact the acceptance of continuous learning. Overall, video technology can be used as a training or educational medium for the youth. Findings of previous studies related to adult learning styles explain that the acceptance of training given to adults is focused on five styles namely i) training environment that requires collaboration between participants, ii) delivery of training activities that emphasize selfconcept, iii) problem solving explicitly, iv) prioritize student-centered learning and v) achievement through appreciation. If these five aspects of adult learning styles are absorbed, training goals will be easily achieved with a variety of teaching mediums (Shaharuddin \& Abiddin, 2016; Rahman et al., 2012; Whitbourne \& Whitbourne, 2014).

Through a questionnaire instrument related to the use of video technology among youths, several findings were obtained. First, the results of this study reveal that youths have been exposed to a high rate of video technology through YouTube applications and social media. This is supported by the findings that shows almost no barriers for respondents using YouTube, Telegram, Facebook and other applications. In addition, the workplace and study environment of the respondents have internet coverage to facilitate the respondents to access information in the form of video. Therefore, the first RQ or objective provides a positive picture of the readiness of the youths involved in this study to use video as a learning medium. 
Second, the findings are based on the second objective, namely, youth acceptance of agricultural videos. The total percentage recorded high for the respondent acceptance construct in this study $(\mathrm{M}=3.87, \mathrm{SP}=0.325)$. This percentage shows that almost all respondents agreed to use the video medium based on ease of obtaining materials, learning is easier and faster to understand and learning motivation increased. This shows that video technology has been accepted to be a medium for the implementation of career training courses that meet the concept of problem solving.

The third finding shows a high tendency of respondents to agree with the advantages of learning through video technology $(M=3.95, S P=0.689)$. The advantages are such as providing thoughtful ideas, convincing an innovation or a new method that is used safely and effectively and can meet the information needs of the youth through digital devices. Thus, the third RQ or objective was answered by showing the majority of respondents agreed agricultural video is a training medium and practical courses are implemented based on the advantages of its suitability functions with adult learning style.

However, there are also weaknesses in implementing video-based learning methods. This was obtained from the answers to the open-ended questions of the respondents 'questionnaires. Not all subjects or exercises can be implemented using video. Learning is according to specific areas. Areas that require detailed practical training and can have a large impact of change, video usage training is not suitable for use. For example, training that involves the use of science laboratories. In addition, internet speed also plays an important role in facilitating learning through video. The internet is the main foundation. If the internet capacity is low, then it is quite difficult to implement learning or training through video. Yet most areas in the country have internet facilities, except in remote areas in the remote villages.

The limitation of this study is from the aspect of data collection which consists of respondents with financial constraints and limited time. Respondents were given brief questions and answers were analyzed descriptively only. Most of the respondents involved were individuals involved with the administration and farming who needed a short time to complete the questionnaire of this study. This study is very much in line with the current situation which is heading towards the 4.0 industry revolution. In this era of industrial revolution, the workforce including in the agriculture and farming is increasingly reduced with the substitution to increasingly advanced robotic technology. Nevertheless, high costs still prevent most institutions and organizations from continuing to contribute employee skills training. Along with the ever-expanding world, available technologies are being put to good use in improving career performance. It is therefore proposed that further research is related to the potential and impact of the latest technologies that can add value to existing video technologies.

\section{Conclusion}

Discussion of findings of the study, particularly the use of video showed positive usage in the field of agriculture on the knowledge and access of agricultural education and training. It is clear that this video-based learning technology opens up many new opportunities to be explored by change agents in enhancing the learning potential of youth. The learning potential of youth will be actively developed as they undergo a self-directed learning process. Therefore, extension agents are advised to be more sensitive to the needs of youth and wise 
in using teaching aids to ensure the development of agriculture achieves the objectives of teaching and learning.

Blogging activities can meet the needs of today's youth who are already surrounded by this highly dynamic and interactive technology. The interaction of farmers by producing and publishing media and sharing with the community can enhance their existing skills as well as be a communication and technical process that they need to become successful and competent farmers in the community. When used effectively in an agricultural environment, vlog videos can redefine classroom boundaries by extending learning experiences outside of schools and institutions into communities that connect agricultural agencies, farmers, consumers and suppliers within the agricultural community. Video vlogs as an emerging tool, popular trends on the web and new ways of media production are widely offered for the production of knowledge sharing materials. Without worry, many farmers will start trying out this exciting tool in a teaching and learning environment for partnership in the near future.

\section{Acknowledgement}

We would like to express our deepest appreciation to the Center for Research of STEM Enculturation, Faculty of Education, Universiti Kebangsaan Malaysia for grant GG-2021-002. Many thanks to all researcher in the project and other researchers in the Personalized Education Research Group for their financial, intellectual, spiritual and moral support.

\section{References}

Albahiri, M. H., \& Alhaj, A. A. M. (2020). Role of visual element in spoken English discourse: implications for YouTube technology in EFL classrooms. Electronic Library 38(3): 531544. doi:10.1108/EL-07-2019-0172

Annisa. (2020). Environmental Education in Grammar Learning Process for Junior High School students by using Multifunctional English Learning Media (MELDe). Journal of Physics: Conference Series 1655(1). doi:10.1088/1742-6596/1655/1/012062

Baharudin, M. A.. \& Ibrahim, M. A. (2020). Kesediaan pelaksanaan pengajaran abad ke 21 dalam kalangan guru pelatih sejarah ipg zon selatan. Jurnal Penyelidikan Sains Sosial 2(5): 32-42.

Bohloko, M., Makatjane, T. J., George, M. J.. \& Mokuku, T. (2019). Assessing the Effectiveness of using YouTube Videos in Teaching the Chemistry of Group I and VII Elements in a High School in Lesotho. African Journal of Research in Mathematics, Science and Technology Education 23(1): 75-85. doi:10.1080/18117295.2019.1593610

Hanifah. (2020). Penggunaan dan penerimaan bahan bantu mengajar multimedia terhadap keberkesanan pembelajaran Geografi. Malaysian Journal of Society and Space 16(3): 219-234. doi:10.17576/geo-2020-1603-16

Hundleby, J. D., \& Nunnally, J. (1994). McGraw Hill Psychometric Theory 3E. 3rd Edition. New York: McGraw Hill.

Kurniawan, E. (2020). A teaching based technology in geography learning. Cypriot Journal of Education 15(4): 61-74. doi:10.18844/cjes.v

Krejcie, R. V., \& Morgan, D. W. (1970). Determining Sample Size for Research Activities. Educational and Psychological Measurement , 30(3), 607-10.

M.Kom, A. (2020). Pemanfaatan Media Sosial Sebagai Media Pembelajaran Pada Mahasiswa Perguruan Tinggi Di Sumsel. Jurnal Digital Teknologi Informasi 1(2): 64. doi:10.32502/digital.v1i2.2371 
Nawi, M. Z. M. (2020). Transformasi Pengajaran dan Pembelajaran Multimedia dalam Pendidikan Islam : Satu Perbincangan. Journal of ICT in Education 7(2): 14-26.

Narzullayevna. (2020). International Journal of Discourse on Innovation, Integration and Education the Practical Importance of Organizing Special Education (August): 20192020.

Rahman, H. A., Awee, A., \& Rajab, A. (2012). Gaya Pengajaran Pembelajaran Pelajar Dewasa Program SPACE Universiti Teknologi Malaysia. Sains Humanika, 58(1).

Shaharuddin, B., \& Abiddin, N. Z. (2016). Tinjauan Faktor-faktor Pendorong dan Penghalang Pemindahan Latihan: Konteks Malaysia. SOSIOHUMANIKA, 2(1).

Vizcaya-Moreno, M. F., \& Pérez-Cañaveras, R. M. (2020). Social media used and teaching methods preferred by generation $\mathrm{z}$ students in the nursing clinical learning environment: A cross-sectional research study. International Journal of Environmental Research and Public Health 17(21): 1-10. doi:10.3390/ijerph17218267

Abdulrahaman, W. A. (2016). The effective use of youtube videos for teaching English. International Journal of English Language and Linguistics Research 4(3): 32-47. Retrieved from http://www.eajournals.org/wp-content/uploads/The-Effective-Useof-Youtube-Videos-forTeaching-English-Language-in-Classrooms-as-SupplementaryMaterial-at-Taibah-University-inAlula.pdf 